\title{
Modeling the Birth Rate of Single-Industry Towns on the Basis of Indicators of Business Demography
}

\author{
Sokolinskaya Yuliya Mikhailovna* \\ Voronezh State University of Engineering Technologies, Russia
}

Submission: August 08, 2019; Published: October 23, 2019

"Corresponding author: Sokolinskaya Yuliya Mikhailovna, Ph.D. in Economics, Voronezh State University of Engineering Technologies, Russia

\begin{abstract}
Without knowledge of business demography, it is impossible to obtain accurate quantitative characteristics of the market situation and conduct their research and forecasting. Without an understanding of the statistical structure of business statistics and statistical studies of the quantitative characteristics of entrepreneurship, any business can suffer serious damage. Only the use of methods of processing statistical indicators, the available data on the business environment can help managers, economists, managers and other consumers of information to form and improve their theories and better understand the processes of business development in the context of the creation of new enterprises, to assess its prospects.
\end{abstract}

Keywords: Statistics; Entrepreneurship; Entrepreneurial activity; Economy; Challenges

JEL Classification: M21; 01

\section{Introduction}

Modern economic relations are practically based on the processes of creation of new enterprises [1-3]. The synchronicity of the economic system, its dynamic stability is provided by the economic mechanism, pursuing common objectives - the creation/ birth of new business structures [4,5]. Growing indicators of demographic processes in business statistics show that everything is going right. Tracking demographic processes allows you to get an idea of the real processes taking place in the economy, to assess how sustainable entrepreneurship is in the current conditions: the processes of creating a really new business or the growth of the number of enterprises are the result of restructuring, etc. $[6,7]$. For example, the analysis of the dynamics of the number of operating enterprises - legal entities and its impact on the level of production should be carried out in close connection with the method of their formation. The formation of new enterprises creates new production capacities and jobs and, therefore, has a greater impact on the improvement of the social situation of the region than the restructuring of existing enterprises [8].

Methodology (materials used, description of the subject, methods and techniques of research).

The main purpose of multiple regression is to build a model with many factors, determining the impact of each of them separately, as well as their cumulative impact on the modeled indicator. Regression equations characterize the isolated influence of a factor on the result, because other factors are fixed at a constant level. The effects of other factors are attached to the free term of the multiple regression equation. They can be compared with each other and respectively to rank the factors according to their impact on the result.

The value of the multiple correlation index ranges from 0 to 1 and must be greater than or equal to the maximum pair correlation index: The closer the value of the multiple correlation index to 1 , the closer the connection of the effective feature with the whole set of factors under study. Comparing the indices of multiple and pair correlation, it can be concluded that it is reasonable (the value of the index of multiple correlation is significantly different from the index of pair correlation) to include this or that factor in the regression equation.

\section{Findings}

To construct a multiple regression model of the birth rate of enterprises, the following characteristics were selected:

Y - fertility organizations 1000 organizations;

X1 - the number of people with monetary incomes below the subsistence minimum, million people (the more people with low income, the more often they are visited by the idea of opening a business to improve the financial situation);

X2 - loans, deposits and other placed funds provided to organizations, individuals and credit organizations, trillion rubles (for loans people can start business); 


\section{Annals of Social Sciences \& Management studies}

\begin{tabular}{|c|c|c|c|c|c|c|}
\hline & $\mathbf{Y}$ & $\mathbf{X 1}$ & $\mathbf{X 2}$ & $\mathbf{X 3}$ & $\mathbf{X 4}$ & $\mathbf{X 5}$ \\
\hline $\mathrm{Y}$ & 1 & 0.163 & -0.032 & 0.142 & -0.207 & 0.053 \\
\hline $\mathrm{X} 1$ & 0.163 & 1 & -0.719 & -0.169 & -0.496 & 0.777 \\
\hline $\mathrm{X} 2$ & -0.032 & -0.719 & 1 & 0.319 & 0.887 & -0.794 \\
\hline $\mathrm{X} 3$ & 0.142 & -0.17 & 0.319 & 1 & 0.303 & -0.23 \\
\hline $\mathrm{X} 4$ & -0.207 & -0.496 & 0.887 & 0.303 & 1 & -0.49 \\
\hline $\mathrm{X} 5$ & 0.053 & 0.777 & -0.794 & -0.23 & -0.49 & 1 \\
\hline
\end{tabular}

people.

Table 2: Estimation of multiple regression model parameters for the fertility rate of organizations for factor characteristics X1-X5.

\begin{tabular}{|c|c|c|c|c|c|c|}
\hline & Regression Coefficient & Standard Error & T- Criterion & P- Value & P-Value Rating & Assessment of The Importance \\
\hline Intersection & 54.8646 & 10.2664 & 5.344 & $8.01 * 10-6$ & $<0.001$ & significant \\
\hline X1 & 0.6375 & 0.2877 & 2.216 & 0.03419 & $<0.05$ & significant \\
\hline X2 & 1.3465 & 0.2557 & 5.265 & $1.00 * 10-5$ & $<0.001$ & significant \\
\hline X3 & 1.4564 & 1.1712 & 1.244 & 0.22299 & $>0.1$ & insignificant \\
\hline X4 & -4.8089 & 0.8688 & -5.535 & $4.63 * 10-6$ & $<0.001$ & significant \\
\hline X5 & 0.6944 & 0.1977 & 3.513 & 0.00138 & $<0.01$ & significant \\
\hline \multicolumn{7}{|c}{ Standard error of regression residuals: 2.956} \\
\hline
\end{tabular}

$Y=54.86+0.638 X 1+1.347 X 2+1.456 X 3-4.809 X 4+0.694 X 5$,

where:

Y - fertility organizations 1000 organizations;

X1 - population with monetary income below the subsistence minimum, million people;

X2 - loans, deposits and other placements provided to organizations, individuals and credit institutions, RUB trillion;

$\mathrm{X} 3$ - entrepreneurial intentions, in \%;

X4 - General level of entrepreneurial activity, in \%;

X5 - number of victims of industrial accidents, thousand thousan
X3 - entrepreneurial intentions, \% (people intending to start a business are involved in the creation of new organizations); higher the overall level of entrepreneurial activity, the more people open their businesses);
X4 - the overall level of entrepreneurial activity, in \% (the
X5 - the number of victims of industrial accidents, thousand people (after industrial injuries, people often think about opening

Graphs and subsequent calculations of the model parameters are obtained in the R (CRAN) environment. The graph of pairwise scatterplots is shown in (Figure 1) (Table 1). their own, safer business).

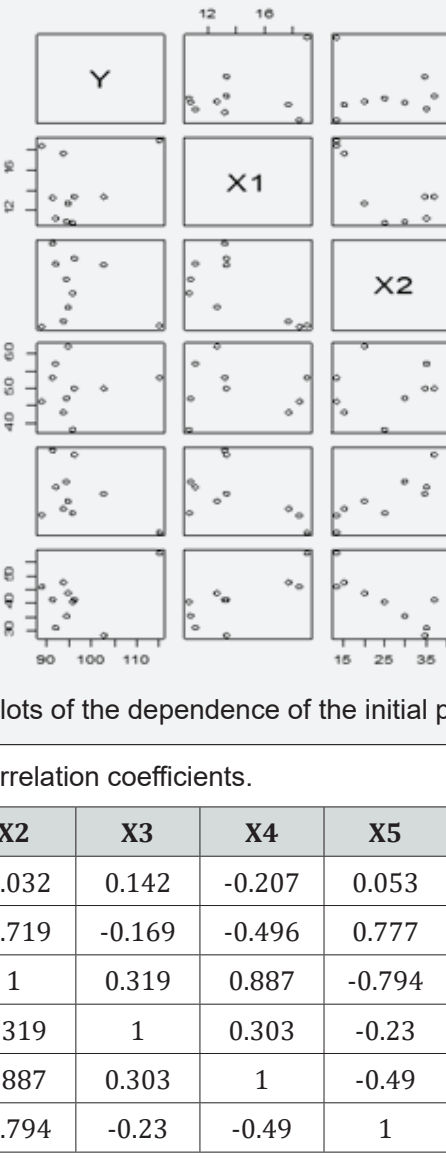

We construct a regression model by step-by-step elimination of factors $[9,10]$. At the initial (zero) stage, a model of the dependence of the effective feature on all factor variables is constructed, the parameters of the initial model and their estimates are presented in (Table 2).

Table 1: Matrix of paired partial correlation coefficients.

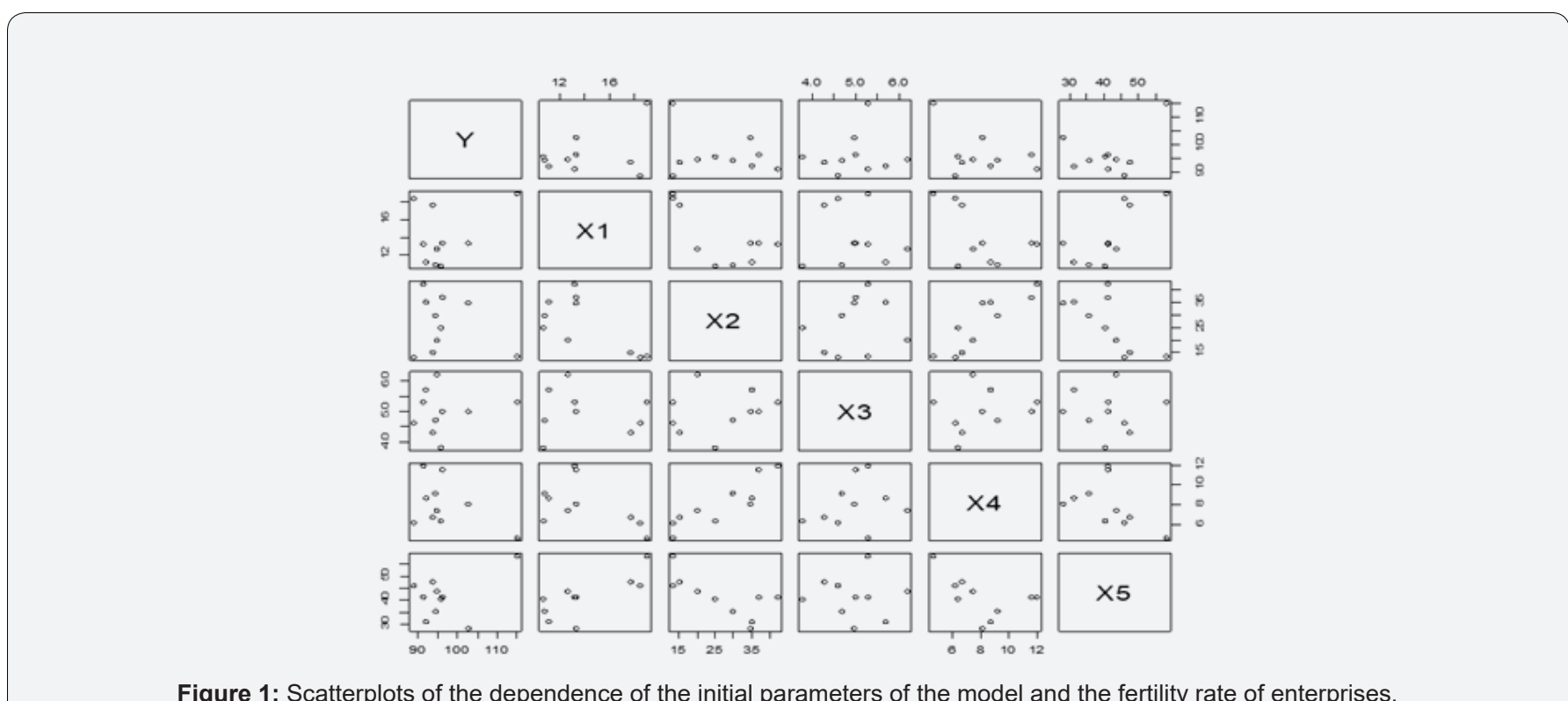

Figure 1: Scatterplots of the dependence of the initial parameters of the model and the fertility rate of enterprises.

The resulting model is as follows:

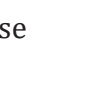




\section{Annals of Social Sciences \& Management studies}

According to (Table 2), the regression equation obtained is very high significant by Fisher's F-test at 95\% confidence level ( $p$-value $=0.00018<0.001$ ), all regression coefficients except X3 are significant at $95 \%$ confidence level. However, due to the insignificance of the regression coefficient $\mathrm{X} 3$, this equation does not allow to predict the fertility rate of enterprises. At the next stage of step-by-step construction of the model and to calculate the parameters of the regression equation for the fertility rate of

Table 3: Estimation of multiple regression model parameters for the fertility rate of organizations for significant factor features.

\begin{tabular}{|c|c|c|c|c|c|c|}
\hline & Regression Coefficient & Standard Error & T- Criterion & P- Value & P-Value Rating & Assessment of The Importance \\
\hline Intersection & 61.1015 & 9.0341 & 6.763 & $1.21 * 10-7$ & $\mathrm{p}<0.001$ & significant \\
\hline X1 & 0.6662 & 0.2892 & 2.303 & 0.028 & $\mathrm{P}<0.05$ & significant \\
\hline X2 & 1.3696 & 0.2572 & 5.324 & $7.73 * 10-6$ & $\mathrm{P}<0.001$ & significant \\
\hline X4 & -4.7917 & 0.8761 & -5.469 & $5.07 * 10-6$ & $\mathrm{P}<0.001$ & significant \\
\hline X5 & 0.6906 & 0.1993 & 3.465 & 0.00153 & $\mathrm{P}<0.01$ & significant \\
\hline \multicolumn{7}{|c}{$\begin{array}{r}\text { Standard error of regression residuals: } 2.981 \\
\text { Multiple R-square: } 0.5065 \text {, Correction R-square: } 0.4448\end{array}$} \\
\end{tabular}

The resulting equation of the model of the birth rate of enterprises can be written as follows:

$\mathrm{Y}=61 \cdot 1+0,67 \mathrm{X} 1+1,37 \mathrm{X} 2-4,79 \mathrm{X} 3+0,69 \mathrm{X} 4$, where:

Y - fertility organizations 1000 organizations;

$\mathrm{X} 1$ - population with monetary income below the subsistence minimum, million people;

X2 - loans, deposits and other placements provided to organizations, individuals and credit institutions, RUB trillion;

X3 - General level of entrepreneurial activity, in \%;

$\mathrm{X} 4$ - the number of victims of industrial accidents, thousand people.

The calculated value of the F-test is 8.211 , p-value $=0.0001<$ 0.001 , the equation is very high significant according to Fisher's enterprises, which would allow to obtain its forecast estimates, the factor characteristic X3 (entrepreneurial intentions, in \%) should be excluded from the initial characteristics and the parameters of the regression equation should be re-evaluated. The obtained regression coefficients of the new equation, their standard errors and the results of their significance evaluation are presented in (Table 3). -test at the 95\% confidence level. Based on (Table 3) all regression coefficients in the model are significant at the 95\% confidence level, which makes it possible to use the obtained model to predict the birth rate of the enterprise. Nevertheless, according to the multiple coefficient of determination, the model allows to describe $50.65 \%$ of the change in the birth rate of enterprises, which, in the author's opinion, is due to its high fluctuation in the existing, for the period under review, and characterized by increased instability of the economic development conditions and economic expectations of persons engaged in or planning to engage in entrepreneurial activity. Standardized regression coefficients (beta-coefficients) of the obtained model are presented in (Table 4).

Table 4: Standardized (b-coefficients) multiple regression model of the birth rate of organizations.

\begin{tabular}{|c|c|c|c|c|}
\hline (Intersection) & $\boldsymbol{\beta 1}$ & $\boldsymbol{\beta 2}$ & $\boldsymbol{\beta 3}$ & $\mathbf{B 4}$ \\
\hline 0 & 0.475 & 3.228 & -2.28 & 1.13 \\
\hline
\end{tabular}

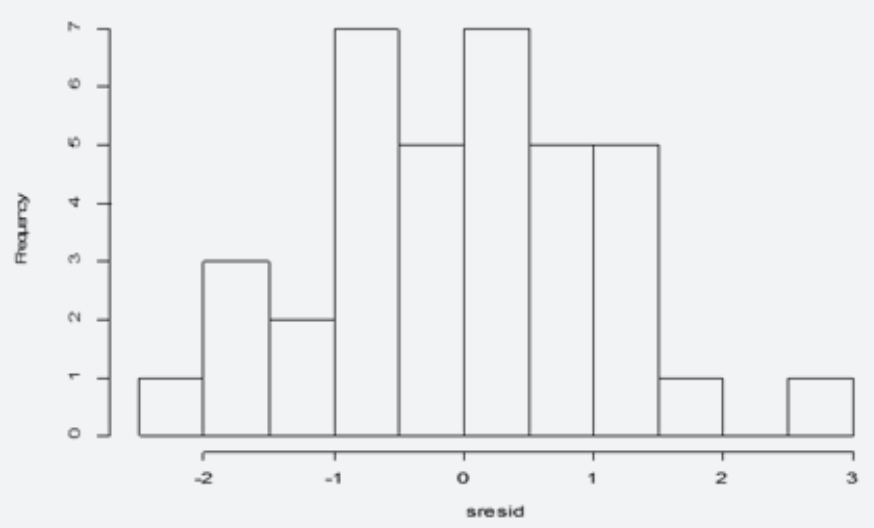

Figure 2: Histogram of the distribution of regression residues of the model of the birth rate of organizations.

Thus, the size of the amount of loans, deposits and other placed funds provided to organizations, individuals and credit institutions affects the birth rate of organizations to the greatest extent, while the population with incomes below the subsistence minimum is the smallest. The increase in the amount of loans, deposits and other placements provided to organizations, individuals and 


\section{Annals of Social Sciences \& Management studies}

credit organizations by $1 \%$ leads to an increase in the birth rate by $3.23 \%$. The increase in entrepreneurial activity by $1 \%$ causes a decrease in the birth rate of organizations by $2.28 \%$. The increase in the number of victims of industrial accidents by $1 \%$ causes an increase in the birth rate by $1.13 \%$. The increase in the number of people with incomes below the subsistence minimum corresponds to an increase in the birth rate of organizations by $0.48 \%$. The histogram of the distribution of regression residues is shown in (Figure 2). The actual and theoretical distribution of the regression residuals is shown in (Figure 3). Analysis of graphs allows us to conclude that the distribution of regression residues corresponds to normal.

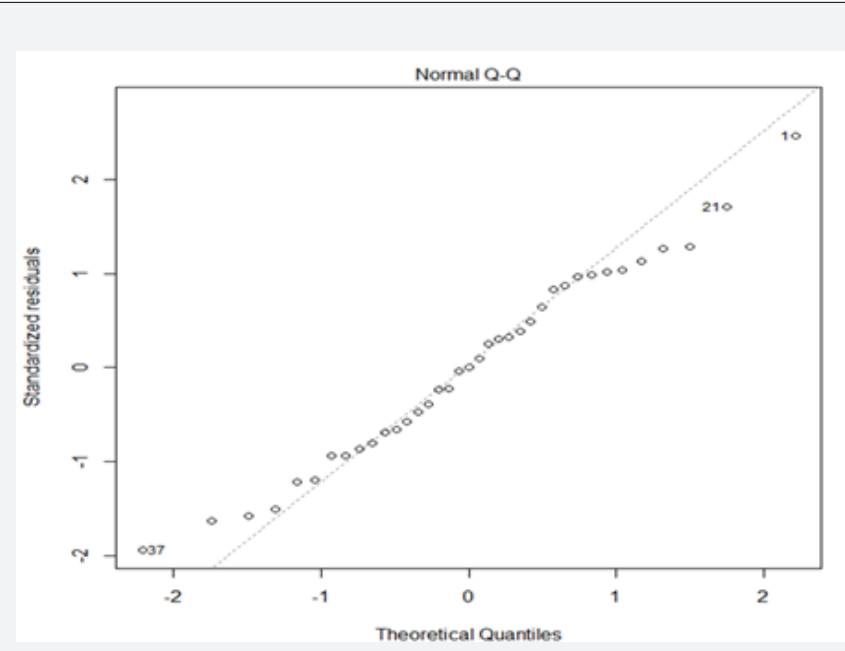

Figure 3: Diagonal graph of the distribution of regression residuals of the birth rate model of organizations.

\section{Conclusion}

The proposed data can be used both individually and jointly as part of more complex forecasts and models (depending on the specific economic conditions and the possibility of identifying the included parameters) for decision-making in the field of optimizing the state economic policy to support and stimulate entrepreneurial activity in single-industry towns.

\section{References}

1. Bosma N, Schutjens V (2011) Understanding regional Variation in Entrepreneurial Activity and Entrepreneurial Attitude in Europe. Annals of Regional Science 47(3): 711-742.

2. Friedman JH (1989) Regularized Discriminant Analysis. Journal of the American Statistical Association 84(405): 165-175.

3. Fritsch M, Storey DB (2014) Entrepreneurship in a regional context: Historical roots, recent developments and future challenges. Regional Studies 48(6): 939-954.
4. Chepurenko A (2015) Entrepreneurship Theory: New Challenges and Future Prospects. Foresight-Russia 9(2): 44-57.

5. West J, Bogers M (2014) Leveraging External Sources of Innovation: A Review of Research on Open Innovation. Journal of Product Innovation Management 31: 814-831.

6. Sibirskaya E, Stroeva O, Simonova E (2015) The characteristic of the institutional and organizational environment of small innovative and big business cooperation. Procedia Economics and Finance 27: 507-515.

7. Stroeva O, Sibirskaya E, Shmanev S (2015) Character regional innovative policy. Procedia Economics and Finance 27: 516-521.

8. National report (2019) Global Entrepreneurship Monitor. Russia. 2016/2017.

9. Johannisson B (2007) Enacting local economic development - theoretical and methodological challenges. Journal of Enterprising Communities: People and Places in the Global Economy 1(1): 7-26.

10. London T, Anupindi R, Sheth S (2010) Creating mutual value: Lessons learned from ventures serving base of the pyramid producers. Journal of Business Research 63: 582-594.

\begin{tabular}{|l|}
\hline \multicolumn{1}{|c|}{ Your next submission with Juniper Publishers } \\
will reach you the below assets \\
- Quality Editorial service \\
- Swift Peer Review \\
- Reprints availability \\
- E-prints Service \\
- Manuscript Podcast for convenient understanding \\
- Global attainment for your research \\
- Manuscript accessibility in different formats \\
( Pdf, E-pub, Full Text, Audio) \\
- Unceasing customer service \\
Track the below URL for one-step submission \\
https://juniperpublishers.com/online-submission.php \\
\hline
\end{tabular}

